\title{
Can Swiss Ball Exercise Technique Reduce Menstrual Pain Intensity in Tahfidzul Qur'an Islamic Boarding School Ibnu Abbas Klaten?
}

\author{
$1^{\text {st }}$ Sri Wahyuni \\ DIII Midwifery Study Program \\ STIKES Muhammadiyah Klaten \\ Klaten, Indonesia \\ *sri.yuni2402@gmail.com \\ $4^{\text {th }}$ Ida Nur Hidayah \\ DIII Midwifery Study Program \\ STIKES Muhammadiyah Klaten \\ Klaten, Indonesia
}

\author{
$2^{\text {nd }}$ Lilik Hartati \\ DIII Midwifery Study Program \\ STIKES Muhammadiyah Klaten \\ Klaten, Indonesia
}

\author{
$3^{\text {rd }}$ Anna Uswatun Qoyyimah \\ DIII Midwifery Study Program \\ STIKES Muhammadiyah Klaten \\ Klaten, Indonesia
}

\begin{abstract}
The purpose of this research was to determine the effect of the Swiss ball exercise technique on decreasing the intensity of menstrual pain in teenage girl. The design used is quasi experiment. The research subjects were 40 teenage girls using purposive sampling consisting of 20 subjects as the intervention group and 20 respondents as the control group. The Swiss ball exercise technique is carried out once a day for 15 minutes for 2 days by using a ball made of rubber with a size depending on the subject's height, pain scale is measured by the Numeric Rating Scale questionnaire. The results of the research showed a significant decrease in menstrual pain levels in teenage girls ( $p$ value $=0,000)$. This proves that the Swiss ball exercise technique has a significant effect in reducing the level of menstrual pain in teenage girls at the Islamic Boarding School Tahfidzul Qur'an Ibnu Abbas Klaten.
\end{abstract}

Keywords-Swiss Ball Exercise, Technique Reduce Menstrual Pain, Tahfidzul Qur'an Islamic Boarding School

\section{INTRODUCTION}

Periodically, normal women will experience menstruation regularly. This process takes place routinely every month for every normal woman. Generally, there are no significant complaints regarding the menstruation except a slight heartburn or emotional instability. However, there are also women who have more in-depth complaints because the menstrual process has been felt to be problematic in terms of cycles, blood counts or pain ${ }^{1}$

Menstrual pain is a symptom and not a disease. Menstrual pain is one of the most common gynecological complaints in adolescents. Almost all women experience discomfort during menstruation, such as discomfort in the lower abdomen and are usually accompanied by nausea, dizziness, even fainting ${ }^{2}$

Menstrual pain if it is not treated it can cause discomfort in every woman and interfere with daily activities ${ }^{9}$. Pharmacological therapies that can be used are Non-Steroids Anti-Inflammatory Analgesics (NSAIDs), for example paracetamol, mefenamic acid, and metamizole, but there are negative effects when using drugs continuously ${ }^{2}$
Non-pharmacological therapy that can be carried out to reduce menstrual pain is acupressure and stretching, endorphin massage ${ }^{3}$. However, there are other techniques called Swiss ball exercise which is one of the nonpharmacological management that is safe because it uses more physiological processes ${ }^{4}$. Research results from ${ }^{5}$ says by doing an exercise the body will produce endorphins produced in the brain and spinal cord. This hormone functions as a natural sedative, giving rise to a sense of comfort ${ }^{10}$.

Based on preliminary studies conducted by researchers on 10 teenage girls, 9 teenage girls experience menstrual pain while 1 teenage girl does not experience menstrual pain. Teenagers experience abdominal pain, feel tired, dizzy, decreased appetite, irritability and lazy to move. The handling that teenagers do, 5 teenage girls claimed to rest when menstrual pain, 3 teenage girls took painkillers and 1 of them continued to do activities. Of all the teenage girls, they say they do not know and have never conducted swiss ball exercise.

The purpose of this research is to determine the effect of the Swiss ball exercise technique on the reduction in menstrual pain intensity at the Tahfidzul Qur'an Islamic Boarding School Ibn Abbas Klaten".

\section{METHODOLOGY}

The method used in this research was a quasi experimental design with a non equivalent control group design. The population used is teenage girls in Tahfidzul Qur'an Islamic Boarding School Ibn Abbas Klaten. The research sample consisted of 40 subjects taken based on a purposive sampling technique consisting of 20 respondents in the intervention group and 20 respondents in the control group that were determined based on inclusion and exclusion criteria.

The independent variable in this study is the Swiss ball exercise technique and the dependent variable is a decrease in the intensity of menstrual pain. Data collection using the Numeric Rating Scale (NRS) pain scale questionnaire. To test the comparison of two measurements the t-test was used 


\section{RESULTS}

A. FINDING

1) Pain Level Before (Pretest)

TABLE 1. FREQUENCY DISTRIBUTION OF PAIN LEVELS BEFORE PERFORMING A SWISS BALL EXERCISE TECHNIQUE

\begin{tabular}{|c|c|c|c|c|c|}
\hline \multirow{2}{*}{ No } & \multirow{2}{*}{ Level of Pain } & \multicolumn{2}{|c|}{ Intervention } & \multicolumn{2}{|c|}{ Control } \\
\hline & & $\mathrm{N}$ & $\%$ & $\mathrm{~N}$ & $\%$ \\
\hline 1 & No pain & 0 & 0 & 0 & 0 \\
\hline 2 & Mild Pain & 3 & 15 & 8 & 40 \\
\hline 3 & Moderate Pain & 16 & 80 & 11 & 55 \\
\hline 4 & Controlled Severe Pain & 1 & 5 & 1 & 5 \\
\hline 5 & Uncontrolled Severe Pain & 0 & 0 & 0 & 0 \\
\hline & Total & 20 & 100 & 20 & 100 \\
\hline
\end{tabular}

Based on table 1, it is known that before performing the Swiss ball exercise technique both the intervention group and the control group there were no teenagers who did not experience menstrual pain and controlled severe pain,

2) Pain Level After (Post Test) while most teenagers experienced moderate pain, namely as many as 16 people $(80 \%)$ in the intervention group and 11 people $(55 \%)$ of respondents were in the control group.

TABLE 2. FREQUENCY DISTRIBUTION OF PAIN LEVELS AFTER PERFORMING SWISS BALL EXERCISE TECHNIQUE

\begin{tabular}{|c|c|c|c|c|c|}
\hline \multirow{2}{*}{ No } & Level of Pain & \multicolumn{2}{|c|}{ Intervention } & \multicolumn{2}{|c|}{ Control } \\
\hline & & $\mathrm{N}$ & $\%$ & $\mathrm{~N}$ & $\%$ \\
\hline 1 & No pain & 4 & 20 & 2 & 10 \\
\hline 2 & Mild Pain & 13 & 65 & 10 & 50 \\
\hline 3 & Moderate Pain & 3 & 15 & 7 & 35 \\
\hline 4 & Controlled Severe Pain & 0 & 0 & 1 & 5 \\
\hline 5 & Uncontrolled Severe Pain & 0 & 0 & 0 & 0 \\
\hline & Total & 20 & 100 & 20 & 100 \\
\hline
\end{tabular}

Based on table 2 it is known that the level of pain after or $(65 \%)$ in the intervention group and 10 people $(50 \%)$ in posttest at most is the level of mild pain by 13 people the control group.

3) Menstrual pain scale before and after treatment

TABLE 3. ANALYSIS OF THE EFFECT OF THE SWISS BALL EXERCISE TECHNIQUE AT THE TAHFIDZUL QUR'AN ISLAMIC BOARDING SCHOOL IBN ABBAS KLATEN

\begin{tabular}{|c|c|c|c|c|c|c|c|c|}
\hline \multirow{2}{*}{ Explanation } & \multicolumn{4}{|c|}{ Before } & \multicolumn{4}{c|}{ After } \\
\cline { 2 - 10 } & Mean \pm SD & $\mathrm{N}$ & Min & Max & Mean \pm SD & N & Min & Max \\
\hline Intervention & $4,75 \pm 1,293$ & 20 & 2 & 7 & $1,90 \pm 1,373$ & 20 & 0 & 4 \\
\hline Control & $3.95 \pm 1,761$ & 20 & 1 & 8 & $3,15 \pm 1,954$ & 20 & 0 & 7 \\
\hline
\end{tabular}

Table 3 shows the level of menstrual pain in the intervention group before being treated with an average of 4.75 and after being treated with an average of 1.90 . Meanwhile the control group showed the average level of menstrual pain beforebeing treatedwas 3.95 and after being treatedwere 3.15 . The pain scale in the intervention group decreased by an average of 2.85 while in the control group it decreased by an average of 0.8 . 
4) Paired T-Test in the Intervention Group

TABLE 4. ANALYSIS OF THE EFFECT OF SWISS BALL EXERCISE TECHNIQUES ON DECREASING THE INTENSITY OF MENSTRUAL PAIN IN ISLAMIC BOARDING SCHOOL TAHFIDZUL QUR'AN IBN ABBAS KLATEN

\begin{tabular}{|c|c|c|c|c|}
\hline Pain Scale & N & Mean & SD & Pval \\
\hline Before & 20 & 4,75 & 1,293 & 0,000 \\
\hline After & & 1,90 & 1,373 & \\
\hline
\end{tabular}

Table 4 shows that the pvalue is $0,000<\alpha(0.05)$, so it can be concluded that there is an effect of the swiss ball exercise technique on decreasing the intensity of menstrual pain in the intervention group.

\section{5) Paired T-Test in the Control Group}

TABLE 5. ANALYSIS OF DECREASING THE INTENSITY OF MENSTRUAL PAIN BEFORE AND AFTER IN THE CONTROL GROUP AT THE ISLAMIC BOARDING SCHOOL TAHFIDZUL QUR'AN IBN ABBAS KLATEN

\begin{tabular}{|c|c|c|c|c|}
\hline Pain Scale & $\mathrm{N}$ & Mean & SD & $\mathrm{P}_{\text {val }}$ \\
\hline Before & 20 & 3.95 & 1,761 & 0,003 \\
\hline After & & 3,15 & 1,954 & \\
\hline
\end{tabular}

Table 5 shows that the $\mathrm{p}$ value is $0.003<\alpha(0.05)$, so it can be concluded that there is a decrease in the level of menstrual pain in the control group.

\section{B. Discussion}

1) Differences in the scale of menstrual pain before and after the Swiss ball exercise technique on the intervention group and the control group

Based on table 3, it shows that the scale of menstrual pain in the intervention group before performing the Swiss ball exercise technique is at moderate pain level or 4.75 and after performing the Swiss ball exercise technique when menstrual pain the pain level becomes 1.90 or mild pain level, whereas in the control group showed 3.95 or mild pain, then after 15 minutes without treatment the level of menstrual pain changed to 3.15

This research was supported by research ${ }^{6}$ titled Effectiveness of Dysmenorrhea Gymnastics on Handling Primary Menstrual Pain in Adolescents, obtained primary menstrual pain after dysmenorrhea gymnastic intervention in the experimental group is 3.07 or mild pain. The decrease in pain scale occurs because excercise is one of the relaxation techniques that allows individuals to provide self-control when there is discomfort or pain, physical and emotional stress on pain. In addition, exercise can also produce endorphin hormone which functions as a natural sedative produced by the brain that makes you feel comfortable and to reduce pain during contractions ${ }^{11}$

2) Effect of swiss ball exercise techniques on decreasing the intensity of menstrual pain in Islamic Boarding School Tahfidzul Qur'an Ibn Abbas Klaten Based on table 4 the experimental group shows that the swiss ball exercise technique is effective on decreasing the intensity of menstrual pain with statistical results $p=0,000 ; \alpha=0.05$, it can be concluded that swiss ball exercise technique has an effect to reduce the intensity of menstrual pain in teenage girls.
The results of this research support the gate control theory proposed by Melzack and Wall that activity or exercise will stimulate the release of endorphins hormone. The mechanism of spinal gates is influenced by the relative amount of activity of large diameter (L) and small diameter (S) primary afferent fibers. If there are impulses that are transmitted by large diameter fibers due to skin stimulation, touch, vibration, warm or cold sensation and soft touch then these impulses will inhibit impulses from small diameter fibers so that the sensations carried by small fibers will be reduced or not delivered to the brain by SG so that the body does not feel the sensation of pain ${ }^{7}$

Swiss ball is an exercise technique using a ball, where the purpose of this exercise is to strengthen muscles, increase ligament flexibility so that lumbar stabilization is improved. Using swiss ball exercises where there is an isometric and isotonic muscle contraction resulting in a vasoconstriction effect on blood vessels where circulation will be smooth and $\mathrm{O}_{2}$ nutrition to the muscles improves ${ }^{5}$

The research results ${ }^{4}$ exercises is proven to increase endorphin levels four to five times in the blood, so the more the physical exercise the higher the endorphin levels so that it can reduce pain during menstruation.

This research is supported by ${ }^{8}$ about core stability exercise as an Effort to Reduce Menstrual Pain in Teenage Girl states that with exercise the body will work to produce endorphins that function to control the condition of blood vessels to be normal again and maintain blood flow so that it can flow easily without obstacles. In addition, the endorphin hormone can also function as a natural analgesic in the body so that menstrual pain experienced by teenage girl during menstruation can be reduced ${ }^{12}$ 


\section{CONCLUSION}

There is an effect of Swiss ball exercise technique on decreasing menstrual pain intensity with $\mathrm{t}$ value $=14.565$ and $\mathrm{p}$ value $=0.000(\mathrm{p}<0.05)$

\section{REFERENCES}

[1] Putri SA, Yunus M, Fanani E. Hubungan Antara Nyeri Haid Terhadap Aktivitas Belajar Pada Siswi Kelas Xi Sma Negeri 52 Jakarta. Preventia. 2017.

[2] Tobergte DR, Curtis S. Pengaruh Nyeri Haid (Dismenorhea) Terhadap Aktifitas Sehari-hari Pada Remaja Di SMP N 2 Ponorogo. J Chem Inf Model. 2013;53(9):1689-1699. doi:10.1017/CBO9781107415324.004

[3] Rahayu A, Pertiwi S, Patimah S, Kunci K. Pengaruh Endorphine Massage Terhadap Rasa Sakit Dismenore Pada Mahasiswi Jurusan Kebidanan Poltekkes Kemenkes Tasikmalaya Tahun 2017. Pengaruh Endorphine Massage Terhadap Rasa Sakit Dismenore Pada Mahasiswi Jur Kebidanan Poltekkes Kemenkes Tasikmalaya Tahun 2017. 2017;3(02):22-30.

[4] Raghav S, Singh A. Role of Swiss Ball Exercises in Reducing Pain, Disability and Improving Muscle Endurance in Patients With Mechanical Low Back Ache. Int J Physiother Res. 2017;5(2):1966-1970. doi:10.16965/ijpr.2017.117

[5] de Souza MC, Jennings F, Morimoto H, Natour J. Swiss ball exercises improve muscle strength and walking performance in ankylosing spondylitis: A randomized controlled trial. Rev Bras Reumatol. 2017;57(1):45-55. doi:10.1016/j.rbre.2016.09.009

[6] Istiqomah P. Efektivias Senam Disminore Dalam Mengurangi Dismenore Pada Remaja Putri Di SMU N 5 Semarang. Progr Stud Ilmu Keperawatan Univ Diponegoro. 2009.

[7] Yoon JS, Lee JH, Kim JS. The effect of Swiss ball stabilization exercise on pain and bone mineral density of patients with chronic low back pain. J Phys Ther Sci. 2013;25(8):953-956. doi:10.1589/jpts.25.953

[8] Wulandari OD, Kesehatan FI, Surakarta UM. Pengaruh senam yoga dan core stability exercise terhadap penurunan nyeri haid ( dismenorea) pada mahasiswi akfis widya husada semarang tahun 2018. 2019.

[9] Amelia M, Surakarta UM. the Effect of Pilates Exercise To Hamper Primary Dysmenorrhea in 18-21 Years Old Adolescents. 2016:413-417.

[10] Yu SY, Lv ZT, Zhang Q, et al. Electroacupuncture is Beneficial for Primary Dysmenorrhea: The Evidence from Meta-Analysis of Randomized Controlled Trials. Evidence-based Complement Altern Med. 2017;2017. doi:10.1155/2017/1791258

[11] Chukwuka A, Ayuba E, Yuguda S. Sonographic Determination of Liver and Spleen Sizes in Patients with Sickle Cell Disease at Gombe, Nigeria. CHRISMED J Heal Res. 2018;5(3):182-186. doi:10.4103/cjhr.cjhr

[12] Malla S, Chahal A, Kiran Tiku R, Kaul B. Effect of Motor Control Exercise on Swiss Ball and PNF Technique on NonSpecific Low Back Pain. Int J Med Res Heal Sci. 2018;7(4):114124. www.ijmrhs.com. 